\title{
HGF/c-Met pathway has a prominent role in mediating antiapoptotic signals through AKT in epithelial ovarian carcinoma
}

\author{
Rong Bu ${ }^{1, *}$, Shahab Uddin ${ }^{1, *}$, Prashant Bavi ${ }^{1}$, Azhar R Hussain ${ }^{1}$, Fouad Al-Dayel ${ }^{2}$, Samir Ghourab ${ }^{3}$, \\ Maqbool Ahmed ${ }^{1}$ and Khawla S Al-Kuraya ${ }^{1}$
}

The Met receptor tyrosine kinase and its ligand, hepatocyte growth factor (HGF), are overexpressed and/or activated in a variety of human malignancies. However, its role in epithelial ovarian carcinoma (EOC) has not been clearly elucidated. Therefore, we investigated the role of HGF/c-Met signaling pathway in a large series (156) of Saudi EOC patient samples, a panel of cell lines, and xenografts in a NUDE mouse model. Using immunohistochemistry, c-Met overexpression was found in $27.2 \%$ Middle Eastern EOC samples and was associated with an advanced tumor stage $(P=0.0187)$. c-Met overexpression was also associated with antiapoptotic markers X-chromosome-linked inhibitors of apoptosis (XIAP) $(P=0.0008)$ and $\mathrm{BCl}-\mathrm{XL}(P=0.0493)$ expression. Treatment of EOC cell lines with PHA665752 causes a dose-dependent inhibition of cell viability and induction of apoptosis. Furthermore, PHA665752 treatment causes dephosphorylation of AKT and downregulation of antiapoptotic proteins XIAP and BCl-XL. In addition, PHA665752-induced apoptosis occurs through activation of Bax-mediated release of cytochrome $c$ and activation of caspases. Finally, co-treatment of EOC with PHA665752 and cisplatin causes augmented effect on apoptosis of EOC cells and resulted in synergistic inhibition of EOC xenograft tumor growth in NUDE mice. These results indicate that c-Met/HGF pathway may be a potential target for therapeutic intervention for treatment of EOC.

Laboratory Investigation (2011) 91, 124-137; doi:10.1038/labinvest.2010.136; published online 26 July 2010

KEYWORDS: AKT; apoptosis; epithelial ovarian carcinoma; hepatocyte growth factor; hepatocyte growth factor/c-Met pathway; tissue microarray

Ovarian cancer is the most lethal of the gynecologic malignancies and this is due in large part to the resistance of recurrent ovarian cancer cells to standard chemotherapeutic strategies. Resistance to apoptotic cell death is a fundamental characteristic of cancer cells, and a primary cause of treatment failure. A critical step in apoptosis is the activation of cysteine-dependent aspartate-specific proteases, the caspases. Once activated, the caspases are responsible for DNA fragmentation and cleavage of numerous critical proteins. Owing to the pathological consequences of deregulated apoptosis, the activation of caspases is under direct and stringent regulation by the inhibitors of apoptosis (IAPs). ${ }^{1} \mathrm{X}$-chromosome-linked IAP (XIAP), the most potent member of the IAP family, binds directly to and blocks the activity of caspases 3 ,
7 , and 9, as well as interferes with the Bax/cytochrome $c$ cell death pathway. ${ }^{2,3}$ It is overexpressed in a variety of cancers, including ovarian, ${ }^{4-6}$ and there is accumulating evidence that XIAP is a major contributor to chemoresistance in ovarian cancer cells. Specifically, downregulation of XIAP expression in ovarian cancer cells increased the sensitivity of the cells to cisplatin- and docetaxel-induced cell death. ${ }^{7-9}$ Studies on the efficacy of antisense oligonucleotides against XIAP (AS XIAP) in vivo show that AS XIAP treatment significantly impeded tumor growth or caused tumor regression in xenograft models representing several types of cancer (prostate, lung, colon, and breast) when administered either as a single agent or in combination with clinically relevant chemotherapy. ${ }^{10,11}$ Recently, downregulation of XIAP expression in

\footnotetext{
'Human Cancer Genomic Research, Research Center, King Faisal Specialist Hospital and Research Center, Riyadh, Saudi Arabia; ${ }^{2}$ Department of Pathology, King Faisal Specialist Hospital and Research Center, Riyadh, Saudi Arabia and ${ }^{3}$ Department of Gynecology, King Faisal Specialist Hospital and Research Center, Riyadh, Saudi Arabia Correspondence: Dr KS Al-Kuraya, MD, FCAP, Human Cancer Genomic Research, Research Center, King Faisal Specialist Hospital and Research Centre, MBC\#98-16, PO Box 3354, Riyadh 11211, Saudi Arabia.

E-mail: kkuraya@kfshrc.edu.sa

*These authors contributed equally to this work.
} 
ovarian cancer cells has resulted in apoptosis in vitro and a prolonged survival time of ovarian cancer-bearing mice. ${ }^{12}$

One of the pathways that has been activated in various epithelial cancers and to modulate tumor cell growth and apoptosis is the hepatocyte growth factor (HGF)/c-Met signaling pathway. ${ }^{13} \mathrm{c}$-Met, a proto-oncogene, is suggested to be associated with ovarian cancer progression. ${ }^{14,15}$ The c-Met contains a tyrosine kinase domain, which is found to initiate various cell function regulating signals through the AKT signaling pathway. Recent studies suggested that HGF/c-Met tyrosine kinase pathway may be influencing antiapoptosis and cell survival of tumor cells. ${ }^{16}$ There is strong evidence for a functional relationship between c-Met and XIAP through AKT in cancer cells: XIAP expression is found to be regulated by $\mathrm{HGF} / \mathrm{c}-$ Met through AKT activity in several cancers. ${ }^{17-19}$

In this study, we assessed the prevalence of c-Met protein expression, its relation to activated AKT, and its downstream antiapoptotic targets such as XIAP and Bcl-XL in a large cohort of Saudi epithelial ovarian carcinomas (EOCs) using tissue microarray (TMA) technology. We next examined the effect of c-Met inhibition on the EOC cell growth both in vitro and in vivo. We finally investigated the effect of c-Met inhibition on the antitumor activity of conventional chemotherapeutic agent in EOC.

\section{MATERIALS AND METHODS}

\section{Patient Selection and TMA Construction}

A total of 156 patients with ovarian carcinoma diagnosed were selected from the files of the King Faisal Specialist Hospital and Research Centre. All samples were analyzed in a TMA format. The Institutional Review Board of the King Faisal Specialist Hospital \& Research Centre approved the study. The patients included in this study had their diagnosis, treatment, and follow-up care in the Departments of Obstetrics and Gynaecology and Oncology at King Faisal Specialist Hospital and Research Centre. The histological subtype of each ovarian tumor sample was determined according to the established criteria. ${ }^{20}$ The distribution of tumors by histologic type was as follows: 125 serous $(80.1 \%)$, 22 endometrioid (13.9\%), 4 clear cell $(2.7 \%)$, and 5 undifferentiated/mixed epithelial (3.3\%) types. The median age of the patient population was 56 years with a range from 19 to 86 years. The majority of patients underwent primary surgical staging or cytoreduction. In some patients who were not fit for primary surgery, primary neoadjuvant chemotherapy was followed by interval debulking surgery. The distribution by FIGO stage at diagnosis was as follows: stages I-II in 8 patients $(5.1 \%)$, stage III-IV in $137(87.8 \%)$, and unknown in $11(7.1 \%)$. The median follow-up time was 14.9 months (range, 1-130 months). Progression-free survival (PFS) was computed from date of surgery for patients who underwent primary cytoreduction and from date of diagnosis by biopsy or cytology in those who underwent primary neoadjuvant chemotherapy. As the majority of patients are lost to follow-up as their disease reaches its terminal stages, it was impossible to determine the overall survival in this specific patient population. TMAs were constructed from formalin-fixed, paraffin-embedded ovarian cancer specimens as described previously. ${ }^{21}$ Tumor regions were mapped by a pathologist for scoring. The TMA was constructed with $0.6 \mathrm{~mm}$ diameter cores spaced $0.8 \mathrm{~mm}$ apart using a modified Tissue Microarrayer (Beecher Instruments, Sun Prairie, WI, USA). The TMA block was cut into $5 \mathrm{~mm}$ sections, adhered to the slide by an adhesive tape-transfer method (Instrumedics, Hackensack, NJ, USA), and UV cross-linked.

\section{Immunohistochemistry}

Immunohistochemical studies on formalin-fixed, paraffinembedded tissue sections were performed as described in earlier studies. ${ }^{22}$ Primary antibodies used, their dilutions, and other information are listed in Supplementary Table. For antigen retrieval, Dako Target Retrieval Solution pH 6.0 (Catalogue number S1700) was used, and the slides were microwaved at $750 \mathrm{~W}$ for $5 \mathrm{~min}$ and then at $250 \mathrm{~W}$ for $30 \mathrm{~min}$. The sections were incubated overnight with c-Met (C-28, rabbit polycloncal Santa Cruz Biotechnology, Santa Cruz, CA, USA) and the Dako Envision Plus System kit was used as the secondary detection system with $\mathrm{DAB}$ as chromogen.

In this study, c-Met was categorized based on an intensity scale ranging from 0 to 3 . In accordance with the previous reports on c-Met staining in ovarian cancer, overexpression was defined as strong staining $(3+)$ of $\mathrm{c}$-Met in the tumor. $^{14,23-25}$ p-AKT, BCL-XL, and XIAP were scored as described previously. ${ }^{26,27}$

\section{Statistical Analysis}

The JMP7 (SAS Institute, Cary, NC, USA) software package was used for data analyses. Survival curves were generated using the Kaplan-Meier method, with significance evaluated using the Mantel-Cox log-rank test. Risk ratio was calculated using the Cox Proportional Hazard model in both univariate and multivariate analyses. The $\chi^{2}$ tests were used to examine the relationship between nominal variables. The limit of significance for all analyses was defined as a $P$-value of 0.05 .

\section{Cell Lines and Culture Conditions}

EOC cell lines, MDAH2774, SKOV3, and OVCAR-3 were cultured in RPMI 1640 medium supplemented with $10 \%$ $(\mathrm{v} / \mathrm{v})$ fetal bovine serum, 100 units $/ \mathrm{ml}$ of penicillin, and 100 units $/ \mathrm{ml}$ of streptomycin at $37^{\circ} \mathrm{C}$ in humidified atmosphere containing $5 \% \mathrm{CO}_{2}$. All experiments were performed in RPMI 1640 containing 5\% serum.

\section{Reagents and Antibodies}

PHA665752 was purchased from Tocris Bioscience (Ellisville, MO, USA). The 3-(4,5-dimethylthiazol-2-yl)-2,5-diphenyltetrazolium bromide (MTT), cisplatin, and Bax (6A7) antibody were purchased from Sigma (St Louis, MA, USA). Antibodies against caspase 3, cleaved caspase 3, caspase 9, 
AKT, p-Akt, p-JNK, p-STAT-3, p-Erk1/2, p-Jak2, p-Src, p-Lyn, c-Met, XIAP, Bcl-XL, and Bid were purchased from Cell Signaling Technologies (Beverly, MA, USA). Cytochrome $c, \beta$-actin, and poly(ADP)ribose polymerase (PARP) antibodies were purchased from Santa Cruz Biotechnology. Caspase 8 antibody was purchased from R\&D (Minneapolis, MN, USA). Antibody against active p38 was purchased from Promega (Madison, WI, USA) and p-Met (Y1230/Y1234/ Y1235) antibody was purchased from Invitrogen (Camarillo, CA, USA). Annexin V was purchased from Molecular Probes (Eugene, OR, USA). Apoptotic DNA-ladder kit was obtained from Roche (Penzberg, Germany).

\section{3-(4,5-Dimethylthiazol-2-yl)-2,5-diphenyltetrazolium Bromide (MTT) Assays}

The anti-proliferative effects of PHA665752 against EOC cell lines were determined by the MTT dye uptake method as described earlier. ${ }^{28}$ Replicates of three wells for each dosage, including vehicle control, were analyzed for each experiment.

\section{Annexin V/Propidium lodide Dual Staining}

EOC cell lines were treated with and without PHA665752 and/or cisplatin as indicated. The cells were harvested and the percentage of cells undergoing apoptosis was measured by flow cytometry after staining with fluorescein-conjugated Annexin $\mathrm{V}$ and propidium iodide (Molecular Probes) as previously described. ${ }^{29}$

\section{DNA Laddering}

DNA-laddering assay was performed as previously described. ${ }^{30}$ Briefly, cells $\left(2 \times 10^{6}\right)$ were treated with and without indicated doses of PHA665752 for $24 \mathrm{~h}$. The cells were harvested and resuspended in $200 \mu \mathrm{l} 1 \times$ PBS. A total of $200 \mu \mathrm{l}$ lysis buffer containing $6 \mathrm{~mol} / \mathrm{l}$ guanidine HCL, $10 \mathrm{mmol} / \mathrm{l}$ urea, $10 \mathrm{mmol} / \mathrm{l}$ Tris- $\mathrm{HCl}$, and 20\% Triton X (v/v; $\mathrm{PH}$ 4.4) were added to the cells and incubated for $10 \mathrm{~min}$ at room temperature. DNA was extracted using Roche apoptotic kit and $2 \mu \mathrm{g}$ of DNA was electrophoresed on a $1.5 \%$ agarose gel containing ethidium bromide at $75 \mathrm{~V}$ for $2 \mathrm{~h}$ and visualized using a UV light source.

\section{Cell Lysis and Immunoblotting}

Cells were treated with or without PHA665752 and/or cisplatin as described in the legends and lysed as previously described. ${ }^{31}$ Proteins $(10 \mu \mathrm{g})$ were separated by SDS-PAGE and transferred to polyvinylidene difluoride (PVDF) membrane (Immobilon, Millipore). Immunoblotting was performed with different antibodies and visualized by the enhanced chemiluminescence (Amersham) method.

\section{Gene Silencing Using siRNA}

Two different c-Met siRNAs (SC-29397 and HSS106477) and scrambled siRNA were purchased from Santa Cruz Biotechnology and Invitrogen (Carlsbad, CA, USA), respectively. Cells were transfected using Lipofectamine 2000 (Invitrogen) for $6 \mathrm{~h}$ after which the lipid and siRNA complex was removed and fresh growth medium was added. Cells were lysed $48 \mathrm{~h}$ after transfection, and specific protein levels were determined by western blot analysis with specific antibodies.

\section{Detection of Bax Conformational Changes}

This assay was performed as described earlier. ${ }^{32}$ Briefly, after treatment with indicated reagents for indicated time points, cells were harvested and washed with PBS, after which they were lysed with Chaps lysis buffer $(10 \mathrm{mmol} / \mathrm{l}$ HEPES ( $\mathrm{pH}$ 7.4), $150 \mathrm{mmol} / \mathrm{l} \mathrm{NaCl}, 1 \%$ Chaps) containing protease inhibitors as described. Protein concentrations were assessed by Bradford assay and $500 \mu \mathrm{g}$ of total protein were incubated with $2 \mu \mathrm{g}$ of anti-Bax $6 \mathrm{~A} 7$ monoclonal antibody for $2 \mathrm{~h}$ at $4^{\circ} \mathrm{C}$. Following incubation, $25 \mu \mathrm{l}$ of protein G-beads were added into the reaction and incubated at $4{ }^{\circ} \mathrm{C}$ overnight on a shaker with gentle agitation. Following washes in lysis buffer, samples were separated by SDS-PAGE, transferred, and immunoblotted with N20 Bax polyclonal antibody.

\section{Measurement of Mitochondrial Membrane Potential}

Cells were treated with and without 5 and $10 \mu \mathrm{M}$ of PHA665752 for $24 \mathrm{~h}$, washed twice with PBS, and suspended in mitochondrial incubation buffer. JC1 was added to a final concentration of $10 \mu \mathrm{mol} / 1$ and cells were incubated at $37^{\circ} \mathrm{C}$ in dark for $30 \mathrm{~min}$. Cells were then washed twice with PBS and resuspended in $500 \mu \mathrm{l}$ of mitochondrial incubation buffer, and mitochondrial membrane potential (\% of green and red aggregates) was determined by flow cytometry as described previously. ${ }^{18,33}$

\section{Assays for Cytochrome c Release}

The release of cytochrome $c$ from the mitochondria was assayed as described earlier. ${ }^{18,33}$ Briefly, cells were treated with and without PHA665752 as described in figure legends, harvested, and resuspended in hypotonic buffer. Cells were homogenized and cytosolic fraction was isolated by differential centrifugation and $20 \mu \mathrm{g}$ of protein from cytosolic fraction of each sample was analyzed by immunoblotting using an anti-cytochrome $c$ antibody.

\section{Animals and Xenografts Study}

Six-week-old NUDE mice were obtained from Jackson Laboratories (Bar Harbor, ME, USA) and maintained in a pathogen-free animal facility at least 1 week before use. All animal studies were performed in accordance with institutional guidelines. For xenograft study, mice were inoculated subcutaneously into the right abdominal quadrant with $10 \times 10^{6}$ MDAH2774 cells in $200 \mu \mathrm{l}$ PBS. After 1 week, mice were randomly assigned into four groups: three groups receiving $3 \mathrm{mg}$ of cisplatin, $25 \mathrm{mg} / \mathrm{kg}$ of $\mathrm{PHA} 665752$, and combination of $3 \mathrm{mg} / \mathrm{kg}$ cisplatin and $25 \mathrm{mg} / \mathrm{kg}$ PHA665752, respectively, and remaining one group receiving $0.9 \%$ saline. The body weight and tumor volume of each mouse was monitored weekly. The tumor volume was measured as 
described earlier. ${ }^{34}$ After 5 weeks treatment, mice were killed and individual tumors were weighted, then snap frozen in liquid nitrogen for storage.

\section{RESULTS \\ Immunohistochemical Detection of c-Met Expression and Its Association with Clinicopathological Parameters in EOC}

c-Met overexpression was seen in $27.2 \%(41 / 151)$ of the EOCs analyzed (Figure 1) and was associated with an advanced tumor stage $(P=0.0187)$. c-Met overexpression was linked to PI3K/AKT signaling pathway as evidenced by direct association with activation of AKT: p-AKT-Ser $473(P=0.0686 ;$ a trend was noted $)$ and downstream antiapoptotic markers XIAP $(P=0.0008)$ and Bcl-XL $(P=0.0493)$ expression. No association was observed between c-Met overexpression and age $(P=0.1268)$, histology type $(P=0.2219)$, and tumor grade $(P=0.5390$; Table 1$)$. EOC patients with high expression of c-Met had a poor PFS of 15.3 months as compared with 16.4 months with low c-Met expression. However, this was not statistically significant $(P=0.3393)$ (Table 1$)$.

\section{PHA665752 Causes Cell Growth Inhibition and Induces Apoptosis in EOC Cells}

We used a panel of EOC cell lines to determine whether inhibition of c-Met tyrosine kinase activity with PHA665752, a c-Met selective inhibitor, leads to growth inhibition of these cancer cells. MDAH2774, SKOV3, and OVCAR-3 cells were treated with $0.5,1,5,10$, and $25 \mu \mathrm{M}$ PHA665752 for $24 \mathrm{~h}$ and cell viability was determined by MTT assays. As shown in Figure 2a, PHA665752 caused a dose-dependent growth inhibition in both cell lines. The growth inhibition mediated by PHA665752 treatment was found to be statistically significant $(P<0.001$, Student's $t$-test $)$ at most of the doses tested in both cell lines. We also determined the concentration of PHA665752 that inhibits 50\% (IC50) of cell growth. The IC50 values calculated from our graphed results were $2.54 \mu \mathrm{M}$ for $2774,5.51 \mu \mathrm{M}$ for SKOV3, and $1.09 \mu \mathrm{M}$ for OVCAR-3 using PRISM (GraphPad Software) software. Therefore, we decided to use 5 and $10 \mu \mathrm{M}$ for further experiments.

In subsequent experiments, we determined whether the observed suppressive effects of PHA665752 in MTT assays are due to cell cycle arrest or induction of apoptosis. Both EOC cell lines were treated with 5 and $10 \mu \mathrm{M}$ PHA665752 for $24 \mathrm{~h}$. The cells were stained and cell cycle fractions were determined by flow cytometry. As shown in Figure 2b, the subG1 population of cells increased from $1.05 \pm 0.77 \%$ in vehicle to $46.88 \pm 0.93 \%$ and $68.34 \pm 2.99 \%$ with 5 and $10 \mu \mathrm{M}$ PHA665752 treatment, respectively, in SKOV3 cells. Similar results were obtained in MDAH2774 (data not shown). These results showed that PHA665752 treatment causes apoptosis in EOC cells. We further used additional Annexin/PI staining and DNA-laddering assays to confirm PHA665752-induced apoptosis in EOC cells. In the following experiments, MDAH2774, SKOV3, and OVCAR-3 cells were treated with PHA665752 and stained with Annexin V/propidium iodide dual staining and apoptosis was detected by flow cytometry. As shown in Figure 2c, there was a dose-dependent increase in the apoptotic cells in both cell lines as seen by an increase of cells in the upper right quadrant depicting apoptotic cells. Treatment with 5 and $10 \mu \mathrm{M}$ PHA665752 of MDAH2774 resulted in $76.56 \pm 4.38$ and $95.26 \pm 5.79 \%$ apoptosis, respectively, SKOV3 showed $59.28 \pm 1.33$ and $85.61 \pm$ $3.21 \%$ apoptosis, respectively, whereas OVCAR-3 showed $62.88 \pm 2.66$ and $79.73 \pm 2.36 \%$, respectively (Figure $2 \mathrm{~d}$ ). Finally, the analysis of DNA fragmentation, a hallmark of apoptosis, was used for further confirmation of PHA665752induced apoptosis. MDAH2774 and SKOV3 cells were treated with various doses of PHA665752 as indicated for $24 \mathrm{~h}$. DNA was isolated using apoptotic DNA-ladder kit from Roche. As shown in Figure 2e, PHA665752 caused a dose-dependent fragmentation formation of DNA, a characteristic of apoptotic cell death. These results suggest that suppression of growth by PHA665752 in EOC cells is through induction of apoptosis.

\section{Constitutive Expression of c-Met and Activation of p-AKT Signaling Pathway in EOC Cells}

As it has been previously reported that c-Met in SKOV3 was overexpressed compared with immortalized ovarian surface epithelial (IOSE) cell lines IOSE-T and IOSE-29, ${ }^{35}$ here we first performed the experiment to determine whether constitutive c-Met levels in MDAH2774 and OVCAR-3 cells are also overexpressed as SKOV3 through comparing the expression levels of c-Met among MDAH2774, OVCAR-3, and SKOV3 cell line cells. MDHA2774, OVCAR-3, and SKOV3 cells in exponential growth were lysed and proteins from each sample was separated on SDS-PAGE and transferred to PVDF membrane, and immunoblotted with antibodies against c-Met. As shown in Supplementary Figure 1, similar to SKOV3, c-Met is also highly expressed in MDAH 2774 and OVCAR-3.

Previous studies showed that PHA665752 may downregulate other RTK pathways, which may be involved in apoptosis. ${ }^{16}$ Hence, we sought to determine whether PHA665752 affects the phosphorylation of other RTKs at the selected doses. MDAH2774 and SKOV3 cells were treated with $0.5,1,5,10$, and $20 \mu \mathrm{M}$ PHA665752 for $4 \mathrm{~h}$. Cells were lysed and proteins were separated on SDS-PAGE and immunoblotted with antibodies against p-P38, p-STAT-3, p-JNK, p-Jak2, p-Lyn, p-Erk1/2, and p-Src. As shown in Supplementary Figure 2, a dose-dependent reduction was seen only on the phosphorylation of c-Met. The level of phospho-p38, phospho-JNK, phospho-STAT-3, phosphoJak2, phospho-Lyn, phospho-Erk1/2, and phospho-Src remained unaffected, indicating that PHA665752 specifically inhibited the phosphorylation of c-met. 


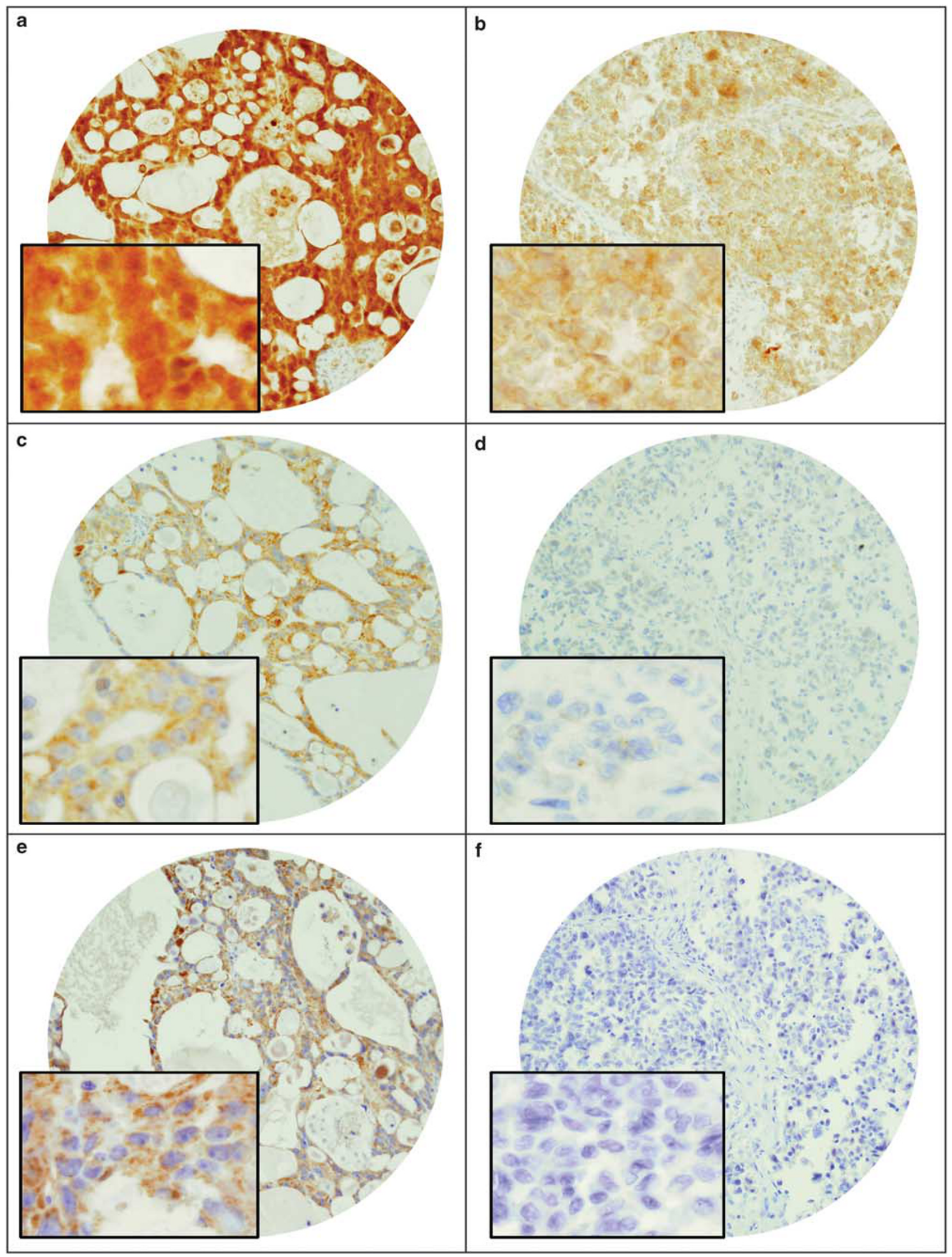


Table 1 Correlation of c-MET expression with clinicopathological parameters in epithelial ovarian carcinoma

\begin{tabular}{|c|c|c|c|c|c|c|c|}
\hline \multirow[t]{2}{*}{ Epithelial group } & \multirow[b]{2}{*}{$N$} & \multirow[b]{2}{*}{$\%$} & \multicolumn{2}{|c|}{ High expression } & \multicolumn{2}{|c|}{ Low expression } & \multirow[t]{2}{*}{$P$-value } \\
\hline & & & $N$ & $\%$ & $N$ & $\%$ & \\
\hline Total number of cases & 151 & & 41 & 27.2 & 110 & 72.8 & \\
\hline \multicolumn{8}{|l|}{ Age } \\
\hline$\leq 50$ years & 59 & 39.1 & 12 & 20.3 & 47 & 79.7 & 0.1268 \\
\hline$>50$ years & 92 & 60.9 & 29 & 31.5 & 63 & 68.5 & \\
\hline \multicolumn{8}{|l|}{ Tumor stage } \\
\hline Stages I-II & 8 & 5.7 & 0 & 0.0 & 8 & 100.0 & 0.0187 \\
\hline Stages III-IV & 133 & 94.3 & 40 & 30.1 & 93 & 69.9 & \\
\hline \multicolumn{8}{|l|}{ Histopathology } \\
\hline Clear cell & 4 & 2.7 & 1 & 25.0 & 3 & 75.0 & 0.2219 \\
\hline Endometriod & 21 & 13.9 & 8 & 38.1 & 13 & 61.9 & \\
\hline Serous & 121 & 80.1 & 32 & 26.4 & 89 & 73.6 & \\
\hline Undifferentiated & 5 & 3.3 & 0 & 0.0 & 5 & 100.0 & \\
\hline \multicolumn{8}{|l|}{ Tumor grade } \\
\hline Well differentiated & 27 & 17.9 & 6 & 22.2 & 21 & 77.8 & 0.5390 \\
\hline Moderately differentiated & 81 & 53.6 & 25 & 30.9 & 56 & 69.1 & \\
\hline Poorly differentiated & 43 & 28.5 & 10 & 23.3 & 33 & 76.7 & \\
\hline \multicolumn{8}{|l|}{$p-A K T(\operatorname{Ser} 473)^{a}$} \\
\hline High (2-3) & 74 & 51.7 & 25 & 33.8 & 49 & 66.2 & 0.0686 \\
\hline Low $(0-1)$ & 69 & 48.2 & 14 & 20.3 & 55 & 79.7 & \\
\hline \multicolumn{8}{|l|}{$X I A P^{\mathrm{a}}$} \\
\hline$>70$ & 128 & 88.9 & 40 & 31.2 & 88 & 68.8 & 0.0008 \\
\hline$\leq 70$ & 16 & 11.1 & 0 & 0.0 & 16 & 100.0 & \\
\hline \multicolumn{8}{|l|}{$B C I-X L^{\mathrm{a}}$} \\
\hline$>180$ & 121 & 86.4 & 37 & 30.6 & 84 & 69.4 & 0.0493 \\
\hline$\leq 180$ & 19 & 13.6 & 2 & 10.5 & 17 & 89.5 & \\
\hline PFS median (months) & & & 15.3 & & 16.4 & & 0.3393 \\
\hline
\end{tabular}

PFS, progression-free survival.

${ }^{\mathrm{a}}$ Analysis failure of some markers for these IHC markers was attributed to missing or non-representative spots.

Figure 1 Tissue-microarray-based immunohistochemical analysis of c-Met, BCl-XL, XIAP in EOC patients. An EOC tissue microarray spot showing overexpression of (a) c-Met, (c) Bcl-XL, and (e) XIAP. In contrast, another EOC tissue microarray spot showing low expression of (b) c-Met, (d) Bcl-XL, and (f) XIAP; $\times 20 / 0.70$ objectives on an Olympus BX 51 microscope (Olympus America, Center Valley, PA, USA). With the inset showing a $\times 40 / 0.85$ aperture magnified view of the same. 
a

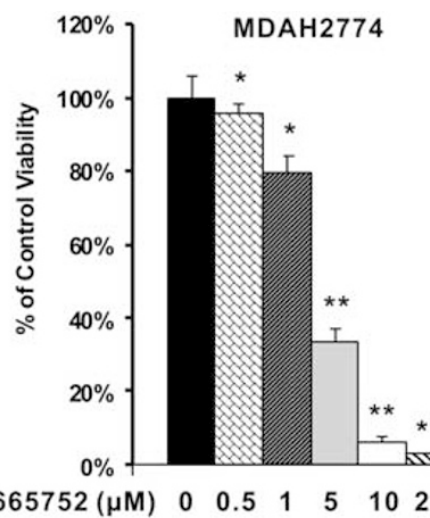

b $\begin{array}{llllllll}\text { PHA } 665752(\mu \mathrm{M}) & 0 & 0.5 & 1 & 5 & 10 & 25\end{array}$ skov3

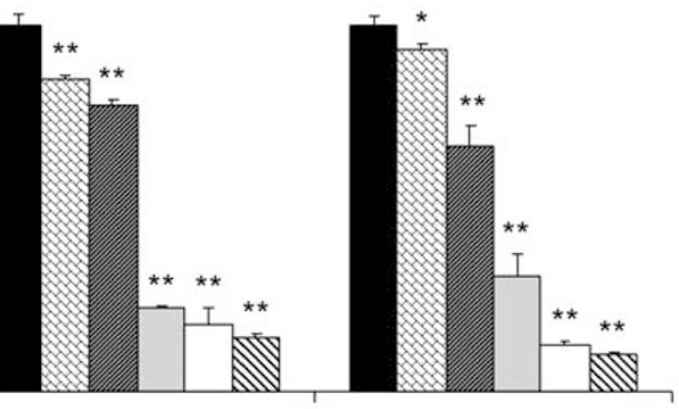

$\begin{array}{llllll}0 & 0.5 & 1 & 5 & 10 & 25\end{array}$$$
\text { c }
$$

PHA665752( $\mu \mathrm{M}) \quad 0$

$\begin{array}{llllll}0 & 0.5 & 1 & 5 & 10 & 25\end{array}$

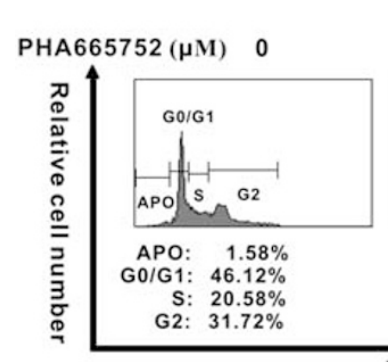

Relative DNA content
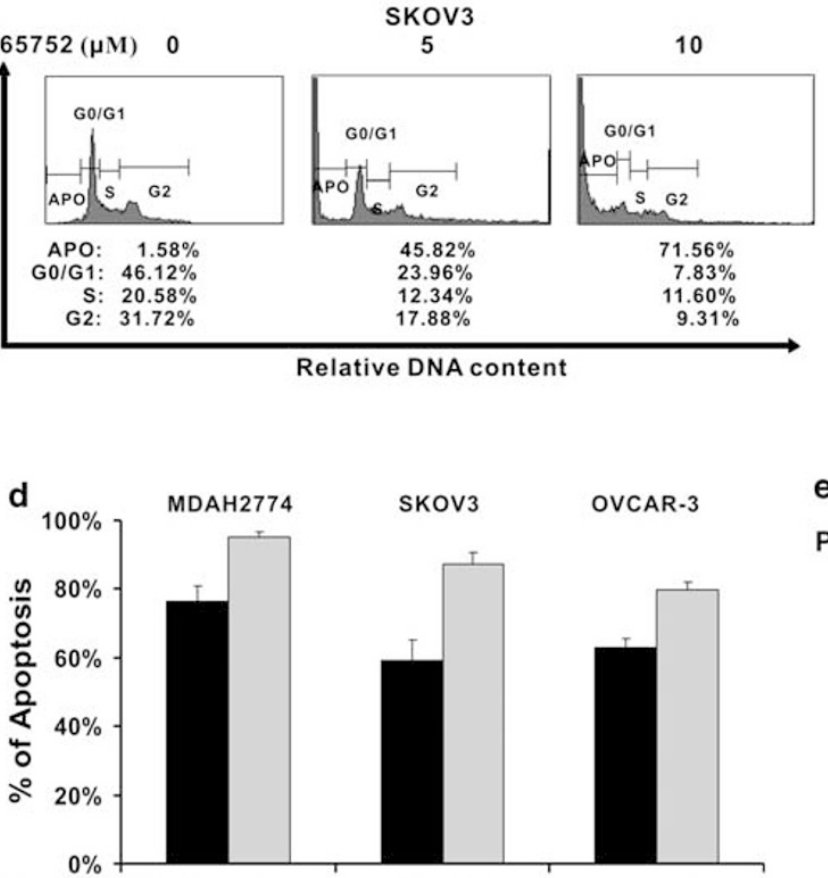

PHA665752 ( $\mu \mathrm{M}) \quad 5 \quad 10$ skov3

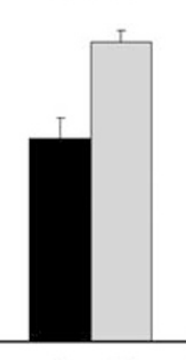

OVCAR-3
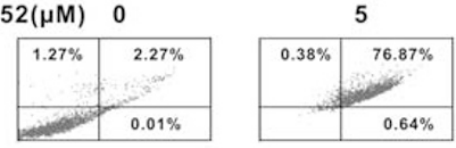

MDAH 2774
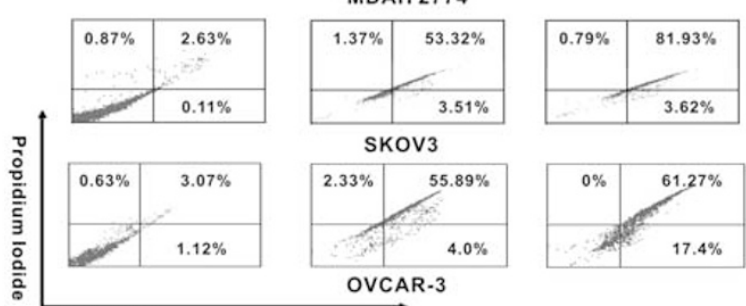

Annexin V

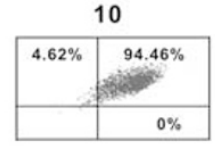

e

MDAH2774

SKOV3
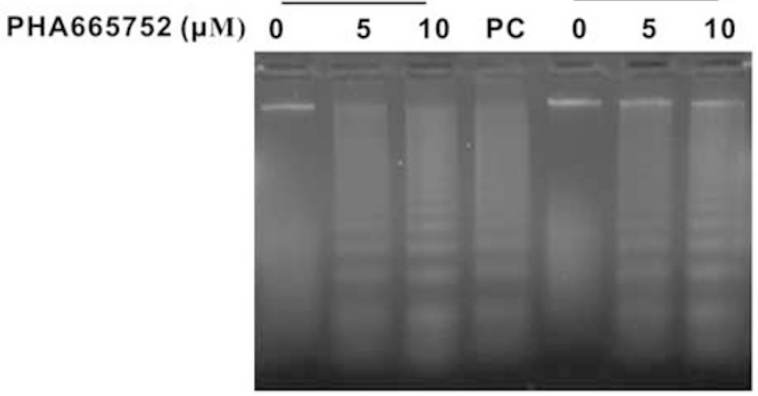

Figure 2 Effect of PHA665752 treatment on cell death in EOC cell lines. (a) PHA665752 inhibits the viability of EOC cells. MDAH2774, SKOV3, and OVCAR-3 cells were incubated with $0,0.5,1,5,10$, and $25 \mu \mathrm{M}$ PHA665752 for $24 \mathrm{~h}$. Cell proliferation assays were performed using MTT as described in Materials and methods. Columns, mean of three independent experiments with replicates of six wells for all the doses and vehicle control for each experiment; bars, s.d. ${ }^{\star} 0.001>P<0.05 ;{ }^{*} P<0.001$, statistically significant (Student's $t$-test). (b) PHA665752 causes cell cycle arrest in SKOV3 cells. SKOV3 cells were treated with 5 and $10 \mu \mathrm{M}$ PHA665752 for $24 \mathrm{~h}$. Thereafter, the cells were washed and stained with propidium iodide, and analyzed for DNA content by flow cytometry. (c) PHA665752-induced apoptosis detected by Annexin V/propidium iodide dual staining. MDAH2774, SKOV3, and OVCAR-3 cells were treated with various doses of PHA665752 (as indicated) for $24 \mathrm{~h}$ and cells were subsequently stained with fluorescein-conjugated Annexin V and propidium iodide and analyzed by flow cytometry. The results from one of three independents experiments have been depicted. (d) PHA665752-mediated apoptosis in MDAH2774 and SKOV3 cell lines. MDAH2774, SKOV3, and OVCAR-3 cell lines were analyzed by flow cytometry after treatment with indicated doses of PHA665752 for $24 \mathrm{~h}$. Columns, mean of three independent experiments; bars, s.d. (e) MDAH2774 and SKOV3 cells were treated with PHA665752 as indicated for $24 \mathrm{~h}$, and DNA was extracted and separated by electrophoresis on $1.2 \%$ agarose gel. PC: positive control from DNA-laddering kit.

It has been reported that HGF/c-Met signaling pathways promote growth and survival of various cancer cells. ${ }^{36,37}$ Therefore, we examined whether inhibition of c-Met activity by PHA665752 also deregulates downstream components of c-Met signaling pathway including p-Met, p-Akt, p-Foxo1, p-GSK3, XIAP, and Bcl-XL in EOC cells. MDAH2774,
SKOV3, and OVCAR-3 cells were treated with 5 and $10 \mu \mathrm{M}$ PHA665752. Cells were lysed and proteins were separated on SDS-PAGE and immunoblotted with various antibodies as indicated. As shown in Figure 3a, all three cell lines expressed constitutive p-Met and p-AKT, and treatment of EOC cells with PHA6657525 dephosphorylated constitutively active 


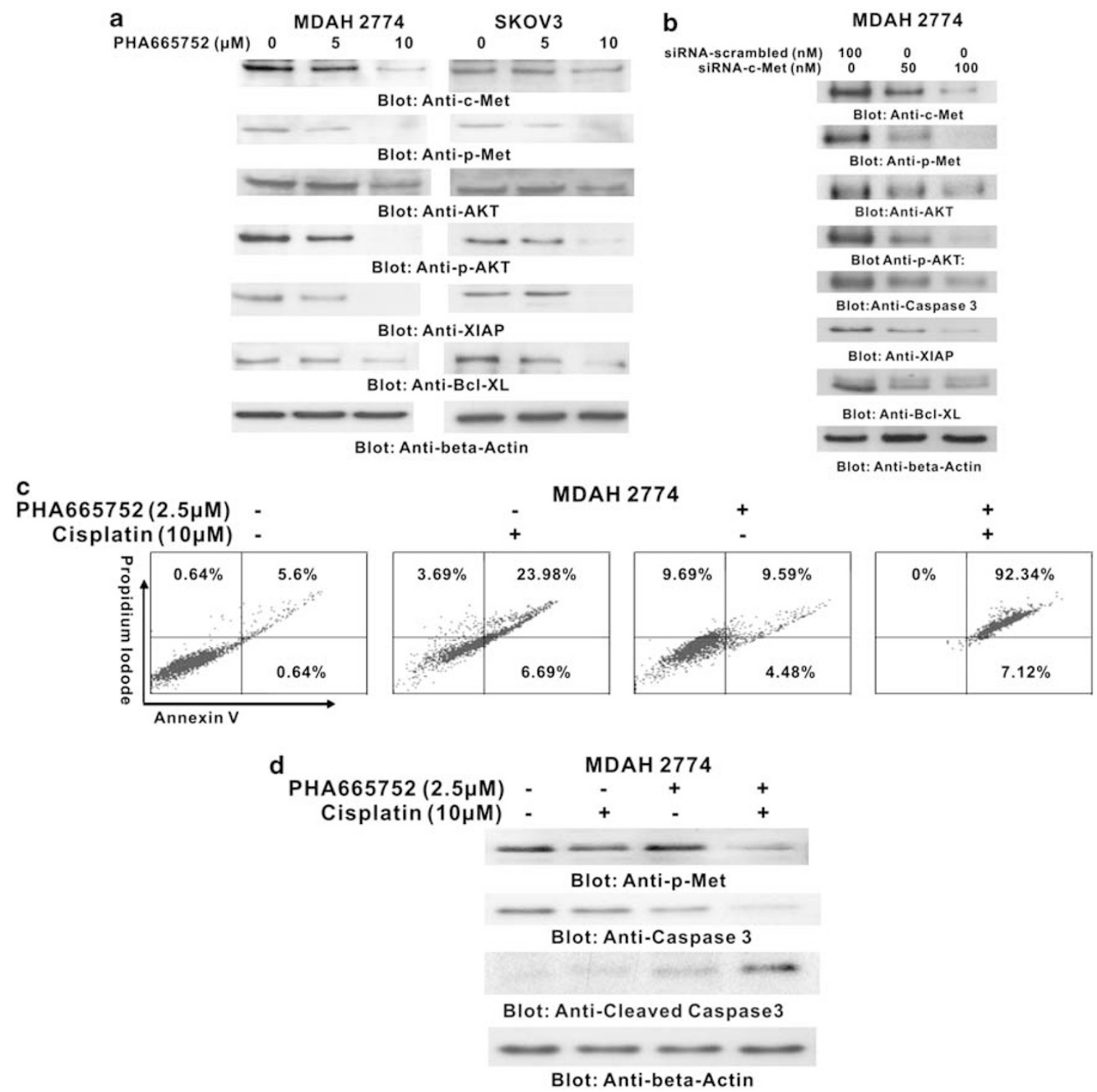

Figure 3 Effect of PHA665752 treatment on c-Met and its downstream signaling pathway. (a) MDAH2774 and SKOV3 cells were treated with various doses of PHA665752 as indicated for $24 \mathrm{~h}$ and cytoplasmic extracts were prepared; $10 \mu \mathrm{g}$ of protein from each sample was separated on SDS-PAGE and transferred to PVDF membrane, and immunoblotted with antibodies against total Met, phosphor-Met, AKT, phosphor-AKT, XIAP, and BCl-XL. The blots were probed with an antibody against $\beta$-actin for equal loading. (b) MDAH2774 cells were transfected with scrambled siRNA (100 nM) and c-Met siRNA (50 and $100 \mathrm{nM}$ ) for $48 \mathrm{~h}$, after $48 \mathrm{~h}$, cells were lysed and proteins were immunoblotted with antibodies against c-Met, p-Met, AKT, p-AKT, Bcl-XL, XIAP, and $\beta$-actin. (c) Effect of cisplatin on PHA665752-induced apoptosis in EOC cells. MDAH2774 cells were treated with $2.5 \mu \mathrm{M}$ PHA665752 alone, $10 \mu \mathrm{M}$ cisplatin alone, and two agents in combination for $24 \mathrm{~h}$ and cell were subsequently stained with fluorescein-conjugated Annexin $\mathrm{V}$ and propidium iodide, and analyzed by flow cytometry. (d) MDAH2774 cells were treated with $2.5 \mu \mathrm{M}$ PHA665752, $10 \mu \mathrm{M}$ cisplatin, and combination of $2.5 \mu \mathrm{M}$ PHA665752 with $50 \mathrm{ng} / \mathrm{ml}$ cisplatin for $24 \mathrm{~h}$ and cells were lysed and equal amounts of proteins were separated on SDS-PAGE, transferred to PVDF membrane, and immunoblotted with antibodies against $\mathrm{p}$-Met, caspase 3 , cleaved caspase 3 , and $\beta$-actin.

p-Met and p-AKT. PHA6657525 treatment of EOC cell lines also inhibited constitutively phosphorylated FOXO1 and GSK3 (data not shown), downstream targets of AKT pathway. In addition, PHA6657525 treatment of EOC downregulated the expression of antiapoptotic genes, XIAP, and Bcl-XL. These data suggest that PHA665752-mediated apoptosis signaling involves c-Met signaling pathway in EOC cells.

To further confirm the mechanism of c-Met-mediated activation of AKT, we treated MDAH2774 cells with $100 \mathrm{ng} / \mathrm{ml}$
HGF in the presence and absence of $5 \mu \mathrm{M}$ PHA665752. Our data showed that HGF phosphorylates c-Met as well as AKT, and pretreatment of MDAH2774 cells with PHA665752 abrogates phosphorylation of c-Met and AKT (Supplementary Figure 3).

In addition, we determined whether treatment of EOC cells with HGF induces upregulation of XIAP. MDAH2774 cells were treated with $100 \mathrm{ng} / \mathrm{ml}$ HGF for 3, 6, 12 , and $24 \mathrm{~h}$. Cells were lysed and proteins were separated on 
SDS-PAGE and immunoblotted with antibody against XIAP. As shown in Supplementary Figure 4a, XIAP upregulated at translational level starting at $3 \mathrm{~h}$ HGF treatment, and maintained the higher expression level until $24 \mathrm{~h}$. In concordance with a previous report in colorectal cancer, ${ }^{19}$ upregulation of XIAP expression at transcriptional level was also observed after treatment of MDAH2774 with HGF (data not shown). We next examined whether HGF induces upregulation of XIAP through activation of AKT. MDAH2774 cells were pretreated with $100 \mathrm{ng} / \mathrm{ml} \mathrm{HGF}$ for $6 \mathrm{~h}$, and then treated with or without $100 \mu \mathrm{M}$ AKT inhibitor for $24 \mathrm{~h}$. Cell lysates were separated on SDS-PAGE and immunoblotted with antibody against XIAP. As shown in Supplementary Figure 4b, treatment of MDAH2774 cells with AKT inhibitor abrogates HGF-induced upregulation of XIAP. These results indicate that $\mathrm{HGF} / \mathrm{c}-\mathrm{Met}$ mediated signaling upregulation of XIAP at both transcriptional and translational level.

Finally, we performed transfection studies with siRNA specifically targeted against c-Met to determine the status of those proteins in MDAH2774 cells to confirm PHA665752induced apoptosis involved in c-Met signaling pathway. As shown in Figure 3b, such as PHA665752, siRNA-targeting c-Met inhibited expression of c-Met, decreased phosphorylation of Met and AKT, and downregulated XIAP and Bcl-XL (Figure $3 \mathrm{~b}$ ). To exclude off-target effects of siRNA resulting from cross-reaction with other targets of similar sequence, we performed additional experiments using a second siRNA against c-Met on MDAH2774 cell line. As shown in Supplementary Figure 5, transfection of this second siRNA also downregulated expression of c-Met, p-Met, p-AKT, Bcl-XL, and XIAP. These results clearly support the link between cMet and XIAP/Bcl-XL through AKT activation in the growth and survival of EOC cells. Inhibition of c-Met/AKT signaling by PHA665752 causes inhibition of cell viability through inducing apoptosis in EOC cells.

\section{PHA665752 Enhanced Antitumor Effects of Cisplatin in EOC}

Cisplatin is a widely used chemotherapeutic agent against various human solid tumors, but its nephrotoxicity and neurotoxicity often limit the treatment. ${ }^{38,39}$ Recent studies have shown that cisplatin induces apoptosis and is enhanced in combination with quercetin and curcumin. ${ }^{40} \mathrm{We}$, therefore, sought to determine whether combination of subtoxic doses of PHA665752 and cisplatin enhances the antitumor effect in EOC cells. MDAH2774 cells were treated with $2.5 \mu \mathrm{M}$ PHA665752, $10 \mu \mathrm{M}$ cisplatin alone or in combination of those two agents for $24 \mathrm{~h}$. Cells were subsequently stained with fluorescein-conjugated Annexin $\mathrm{V}$ and propidium iodide, and analyzed by flow cytometry. As shown in Figure 3c, $2.5 \mu \mathrm{M}$ PHA665752 alone induced $12.51 \pm 4.5 \%$ apoptosis and $10 \mu \mathrm{M}$ cisplatin alone induced $22.43 \pm 8.52 \%$ apoptosis. Combination of PHA665752 and cisplatin together induced $98.54 \pm 0.53 \%$ apoptosis. We next examined the status of p-Met and caspase 3 as apoptotic indicator. MDAH2774 cells were treated with $2.5 \mu \mathrm{M}$ of PHA665752, $10 \mu \mathrm{M}$ cisplatin alone in combination for $24 \mathrm{~h}$. Cell lysates were separated on SDS-PAGE and immunoblotted with antibodies against pMet, caspase 3 and cleaved caspased 3. As shown in Figure $3 \mathrm{~d}$, the expression of p-Met and caspase 3 was significantly decreased, and the level of cleaved caspase 3 was remarkably increased with combination treatment as compared with treated alone. These results clearly suggest that PHA665752 magnifies anticancer effect of cisplatin in EOC cells.

\section{PHA665752 Induces Apoptosis through Involving Mitochondrial Pathway and Activation of Caspases in EOC Cell Lines}

Next, we sought to determine whether inhibition of c-Met signaling involves the mitochondria-mediated apoptotic pathway in the ovarian cancer cells. We first examine the activation of Bax in response to PHA665752 treatment of EOC cell lines. As shown in Figure 4a, inhibition of c-Met led to conformational changes and activation of Bax protein starting at 4 and $8 \mathrm{~h}$ of PHA665752 treatment in both EOC cell lines. We then tested the effect of PHA665752 on mitochondrial membrane potentials in these cells. As shown in Figure 4b, treatment of both cell lines with PHA665752 resulted in loss of mitochondrial membrane potential as measured by JC1-stained green fluorescence depicting apoptotic cells. We then sought to study the release of cytochrome $c$ from mitochondria into cytosole in response to PHA665752 in EOC cells. As shown in Figure 4c, higher level of cytochrome $c$ was measured in cytosolic and lower level in mitochondrial fraction in both cell lines after PHA665752 treatment. Finally, we sought to determine whether PHA665752-induced release of cytochrome $c$ is capable of activation of caspase 9, caspase 3, and cleavage of PARP. Figure 5a shows that PHA665752 treatment resulted in the activation of caspase 9, caspase 3 , and cleavage of PARP in MDAH2774, SKOV3, and OVCAR-3 cell lines in dose-dependent manner. Furthermore, PHA665752 treatment resulted in activation of caspase 8 leading to truncation of Bid in MDAH2774 and SKOV3 cell lines tested, as inferred by decreased intensity of full-length Bid band (Figure 5b). In additional pretreatment of MDAH2774 with $80 \mu \mathrm{M}$ $\mathrm{z}-\mathrm{VAD} / \mathrm{fmk}$, a universal inhibitor of caspases, followed by PHA665752 treatment, abrogated apoptosis from $94.9 \pm 1.12$ to $22.02 \pm 2.9 \%$ in MDAH2774 cells as well as prevented caspase 3 and PARP activation induced by PHA665752 (Figure $5 \mathrm{c}$ and $\mathrm{d}$ ). These results clearly indicate that inhibition of c-Met by PHA665752 causes apoptosis through activation of mitochondrial (intrinsic) apoptotic pathway in EOC cells.

\section{In Vivo Activity of PHA665752 against EOC Cells Xenograft}

Our observation that PHA665752 augmented cisplatin-induced apoptosis in EOC MDAH2774 cells suggests that potential for therapeutic responses for treatment of EOC. 
a
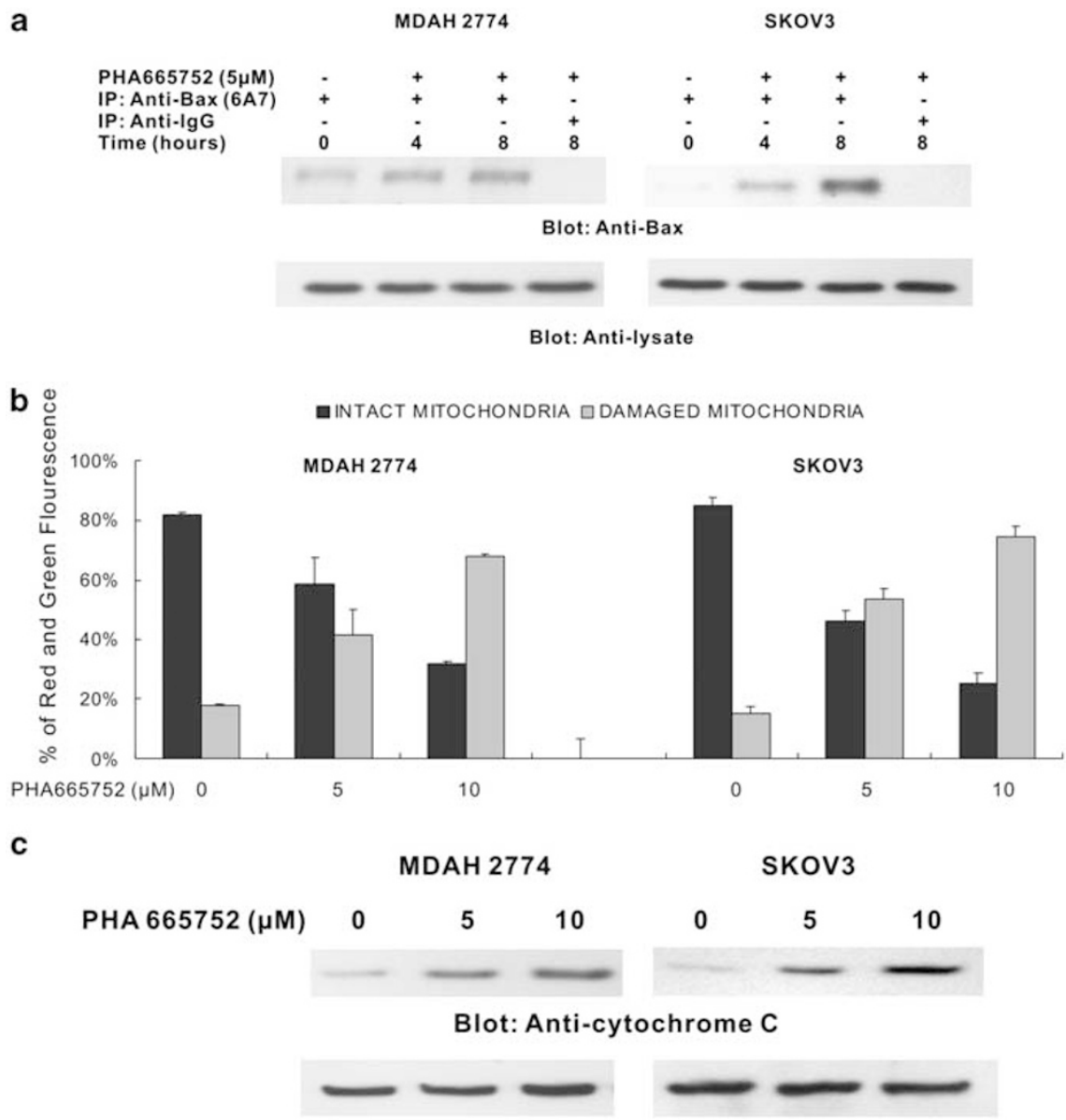

Blot: Anti-beta-actin

Figure 4 PHA665752-induced activation of mitochondrial apoptosis pathway. (a) Bax conformational change by PHA665752 treatment in EOC cell lines. MDAH2774 and SKOV3 cells were treated with $5 \mu \mathrm{M}$ PHA665752 for 4 and $8 \mathrm{~h}$, cells were lysed with $1 \%$ CHAP lysis buffer, and immunoblotted with Bax rabbit polyclonal antibody. (b) Loss of mitochondrial membrane potential by PHA665752 treatment in EOC cells. MDAH2774 and SKOV3 cells were treated with various doses of PHA665752 as indicated for $24 \mathrm{~h}$. Live cells with intact mitochondrial membrane potential (dark column) and dead cells with lost mitochondrial potential (light column) were measured by JC-1 staining and analyzed by flow cytometry as described in Materials and methods. (c) PHA665752-induced cytochrome $c$ release from mitochondria. MDAH2774 and SKOV3 cells were treated with various doses of PHA665752 as indicated for $24 \mathrm{~h}$. Mitochondria-free cytoplasmic fractions were isolated as described in Materials and methods. Cell extracts were separated on SDS-PAGE, and immunoblotted with an antibody against cytochrome $c ; \beta$-actin was used for equal loading.

Therefore, we sought to determine whether co-treatment of PHA665752 with cisplatin potentiates the inhibition of EOC xenograft tumor in NUDE mice. NUDE mice were inoculated subcutaneously 10 million of MDAH2774 cells. Mice were then treated with $25 \mathrm{mg} / \mathrm{kg}$ PHA665752, $3 \mathrm{mg} / \mathrm{kg}$ cisplatin alone, combination of these two agents, or vehicle DMSO $(n=6)$. After 5 weeks of treatment, mice were killed and tumors were collected. As shown in Figure 6a, there was significant regression of tumor volume at the end of third week in the group of animal treated with PHA665752 and cisplatin $(P=0.0175)$ together, and the effect was more profound at the end of fifth week. A significant reduction in tumor weight (Figure 6b) was also observed in mice treated with combination of PHA665752 and cisplatin $(P=0.002)$. In addition, images of tumor after necropsy showed that treatment of these two agents resulted in significant shrinkage of tumor size in NUDE mice (Figure 6c). We further analyzed the status of phosphorylation of c-Met, AKT, and XIAP in MDAH2774 xenograft treated with PHA665752 and cisplatin alone, and group of these two agents. As shown in Figure 6d, the level of p-Met, caspase 3, PARP, XIAP, and Bcl-XL was remarkably deceased, and level of cleaved caspase 3 was significantly increased in tumors of mice treated with PHA665752 and cisplatin, compared with vehicle, PHA665752 alone, and cisplatin alone. Our data indicate that PHA665752 treatment augmented antitumor effects of cisplatin in MDAH2774 cell xenografts in NUDE mice.

\section{DISCUSSION}

HGF has a major role in tumor proliferation, migration, invasion, and metastasis through c-Met pathway in a variety of cancers. ${ }^{13,41}$ Tumorigenic activity of c-Met depends on 


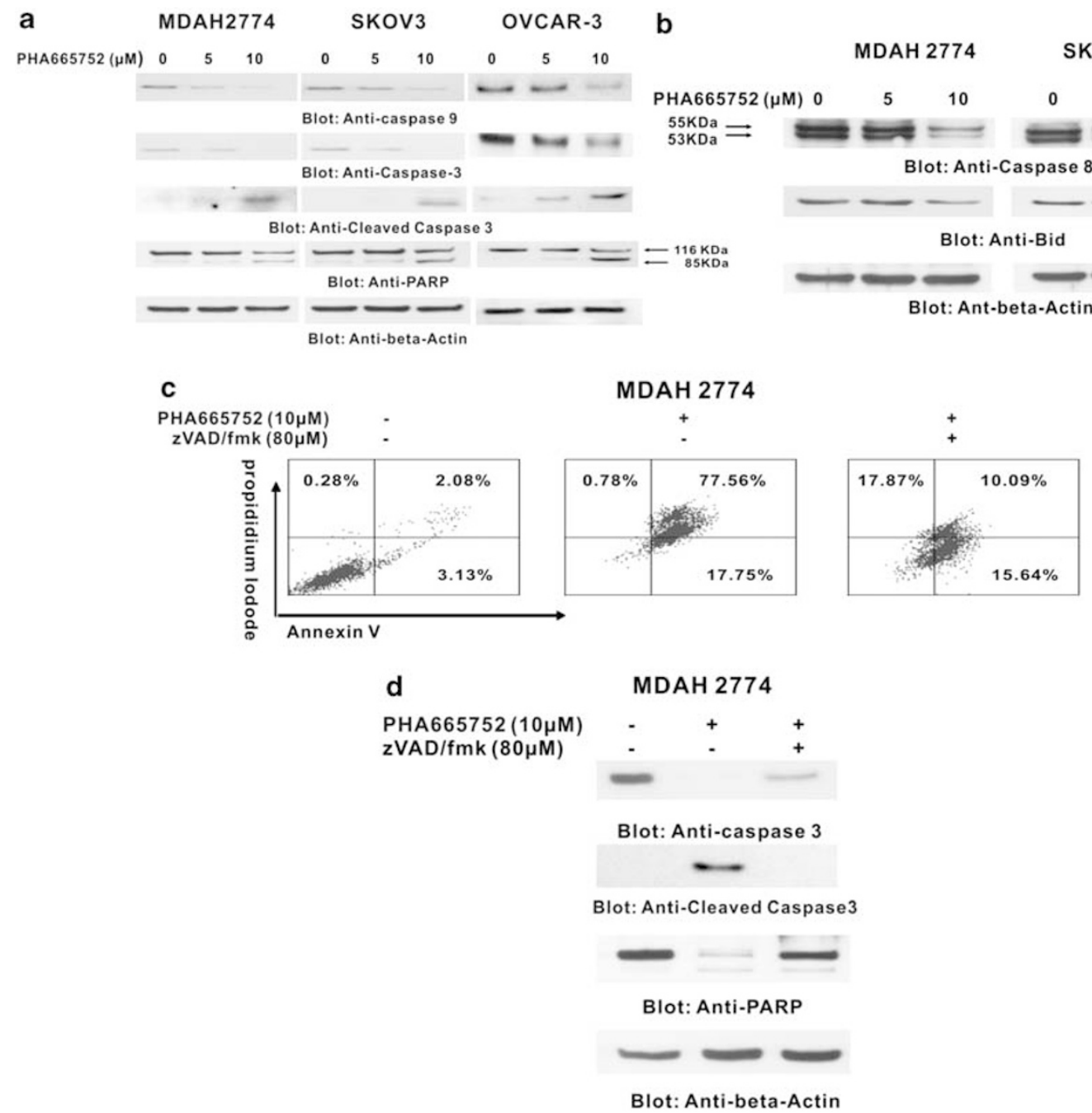

Figure 5 PHA665752-induced activation of caspase 9, caspase 3, caspase 8, cleavage of PARP, and Bid in EOC cells. (a) Caspase 9 and 3 activation and PARP

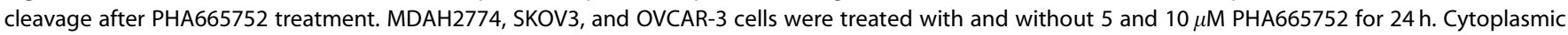
extracts were prepared; $10 \mu \mathrm{g}$ protein from each sample was separated on SDS-PAGE and transferred to PVDF membrane, and immunoblotted with antibodies against caspase 9 , caspase 3 , cleaved caspase 3 , and PARP. The blots were probed with an antibody against $\beta$-actin for equal loading. (b) PHA665752-induced activation of caspase 8 and cleavage of BID. MDAH2774 and SKOV3 cells were treated with various doses of PHA665752 as indicated for $24 \mathrm{~h}$. Cell were lysed and equal amounts of proteins were separated by SDS-PAGE, transferred to PVDF membrane, and immunoblotted with antibodies against caspase 8 and Bid. The blots were probed with an antibody against $\beta$-actin for equal loading. (c) Effect of z-VAD/fmk on PHA665752-induced apoptosis detected by Annexin V/propidium iodide dual staining. MDAH2774 cells were pretreated with $80 \mu \mathrm{M} \mathrm{z-VAD/fmk}$ for $2 \mathrm{~h}$ and subsequently treated with $10 \mu \mathrm{M}$ PHA665752 for $24 \mathrm{~h}$, and cells were subsequently stained with fluorescein-conjugated Annexin $\mathrm{V}$ and propidium iodide and analyzed by flow cytometry. (d) Effect of z-VAD/fmk on PHA665752-induced activation of caspase 3 and cleavage of PARP. MDAH2774 cells were pretreated with $80 \mu \mathrm{M}$ z-VAD/fmk for $2 \mathrm{~h}$ and subsequently treated with $10 \mu \mathrm{M}$ PHA665752 for $24 \mathrm{~h}$ and cells were lysed and equal amounts of proteins were separated on SDS-PAGE and transferred to PVDF membrane, and immunoblotted with antibodies against caspase 3 , cleaved caspase 3 , PARP, and $\beta$-actin.

deregulation of the $\mathrm{HGF} / \mathrm{c}-$ Met signaling pathway that results in phosphorylation and activation of AKT. ${ }^{14-16}$ AKT has an important role in cell survival and antiapoptosis through modulating the expression of antiapoptotic genes. XIAP is an important member of IAP family and its expression correlates not only with antiapoptotic potential, but also with tumor proliferation, metastasis, poor prognosis, and chemotherapeutic resistance in various carcinomas including EOC. ${ }^{12,42-44}$

Recent studies have highlighted the role of HGF/c-Met in regulating XIAP through AKT pathway in colorectal cancer. ${ }^{19}$
We hypothesized that this functional link might exist between c-met and antiapoptotic proteins such as XIAP and Bcl-XL in the pathogenesis of EOC. This hypothesis was confirmed when we found a tight linkage between c-MET and XIAP expression by immunohistochemistry in TMA cohort of 156 Middle Eastern EOC. Although EOC with advanced stage constituted a significant majority of the EOC subset with c-Met overexpression (27\%), c-Met expression did not influence the disease-free survival. Although c-Met expression has been associated with worse outcome in earlier studies, ${ }^{14}$ Di Renzo et $a l^{45}$ found no differences in the survival of 
a

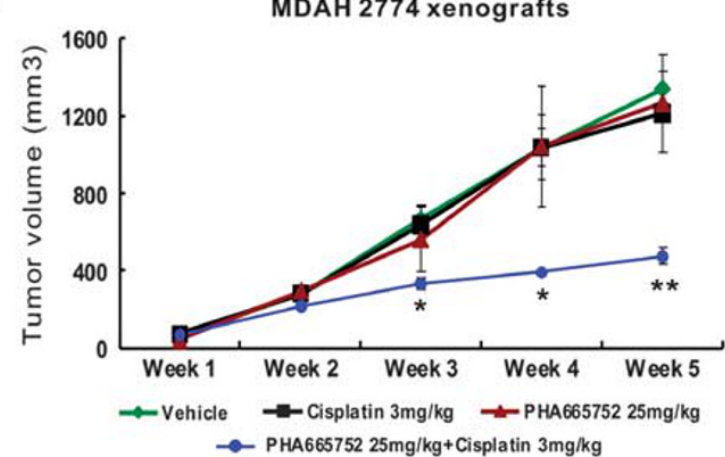

C
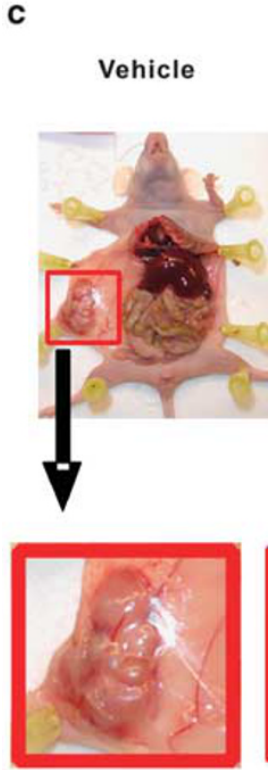

MDAH 2774 xenografts

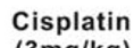
$(3 \mathrm{mg} / \mathrm{kg})$

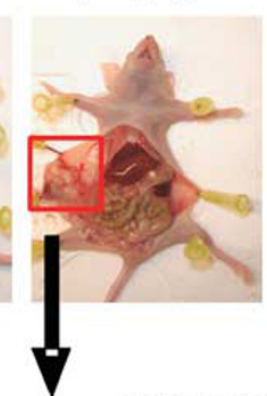

$X 10$ magni

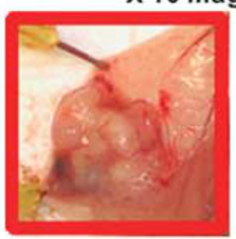

b

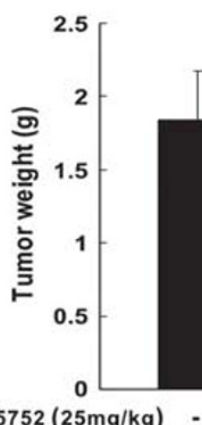

Cisplatin $(3 \mathrm{mg} / \mathrm{kg})$.

d

PHA665752

$(25 \mathrm{mg} / \mathrm{kg})$

Cisplatin

$(3 \mathrm{mg} / \mathrm{kg})$

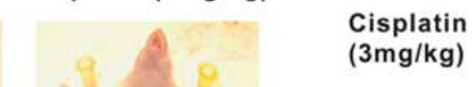

MDAH 2774 xenografts

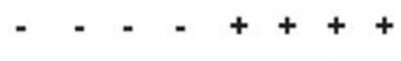

$-\quad++--++$

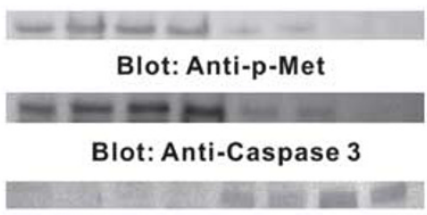

Blot:Anti-Clevead Caspase 3

Blot: Anti-PARP

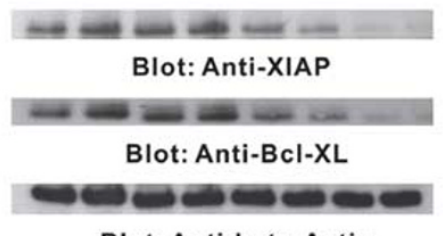

Figure 6 PHA665752 inhibits growth of MDAH2774 xenograft and downregulates c-Met and its downstream signaling pathway in vivo. NUDE mice at 6 weeks of age were injected with 10 million MDAH2774 cells. (a) Effect of PHA665752 on MDAH2774 xenograft. The volume of each tumor was measured every week. The average $(n=6)$ tumor volume in vehicle-treated mice and treated with indicated doses of cisplatin, PHA665752 alone, and combination of cisplatin and PHA665752 were plotted. The results are expressed as mean \pm s.d. $(n=6)\left({ }^{*} 0.01<P<0.05,{ }^{*} P=0.006\right.$ compared with vehicle-treated mice). (b) After 5 weeks of treatment, mice were killed and tumor weights were measured. The results are expressed as mean $\pm s . d$. ${ }^{\star} P=0.002$ compared with vehicle-treated mice by Student's $t$-test. (c) Representative tumor images of vehicle-treated mice and mice treated with PHA665752 and/or cisplatin after necropsy. (d) Whole cell homogenates from mice treated with vehicle, $3 \mathrm{mg} / \mathrm{kg}$ cisplatin, $25 \mathrm{mg} / \mathrm{kg}$ PHA665752, and combination of $3 \mathrm{mg} / \mathrm{kg}$ cisplatin and $25 \mathrm{mg} / \mathrm{kg}$ PHA665752 were immunoblotted with p-Met, caspase 3, cleaved caspase 3, PARP, and XIAP and Bcl-XL antibodies.

patients stratified by c-Met expression. Owing to this strong correlation between c-Met and XIAP expression in EOC tissue samples, we focused our investigation on modulating expression of important antiapoptotic molecules, XIAP and Bcl-XL through inhibition of c-Met. Using EOC cell lines in which the constitutive c-Met is highly expressed, we first showed the c-Met can regulate important biological phenomena such as cell viability and survival. Here, we show the efficacy of PHA665752 in inhibiting c-Met activation resulting in inhibition of cell growth followed by apoptosis in ovarian cancer cell lines. Importantly, in the EOC cell lines, HGF stimulation significantly increased XIAP expression, but this effect was blocked by c-Met siRNA and AKT-specific inhibitor. These results suggest that the XIAP is regulated by HGF/c-Met pathway through AKT activation in EOC.
Though it has been reported that in some experimental conditions including long-term pretreatment ( $48 \mathrm{~h}$ or more) with $\mathrm{HGF}^{46,47} \mathrm{HGF}$ sensitizes ovarian carcinoma cell lines to cisplatin and paclitaxel mediated by p38 mitogen-activated protein kinase, it is worth noting that HGF does not induce apoptosis by itself, indicating that this role is to facilitate apoptosis triggered by the chemotherapeutic agents. ${ }^{48}$ Our data are consistent with that HGF protects cells from apoptosis induced by chemotherapeutic agents, radiation, growth factor deprivation, etc in most physiologic and pathologic scenarios. ${ }^{49-51}$

HGF has been known to activate AKT through the c-Met signaling pathway. ${ }^{17,52} \mathrm{We}$ and others have shown that activated AKT (phosphorylated AKT) negatively regulates apoptotic pathways. ${ }^{53,54}$ In particular Uddin et al ${ }^{30}$ showed 
that XIAP is a direct port transcriptional downstream target of AKT and an important mediator of AKT on cell survival. Our in vitro results support that HGF/c-Met pathway activates antiapoptosis through AKT and XIAP activation. In support for this, we showed that c-Met gene knockout with c-Met SiRNA or chemical inhibitor PHA665752 of EOC cell lines significantly abrogated c-Met expression and HGF effect on upregulation of XIAP and p-AKT.

Furthermore, our in vitro data confirm a sensitivity of EOC cells to c-Met inhibition and this apoptotic response is significantly enhanced after combination therapy using cisplatin with PHA665752. Such selectivity suggests that c-Met inhibitor may be new candidate of chemotherapeutic agent for EOC treatment alone or in combination with other conventional chemotherapeutic agents.

Together, we have shown that c-Met is overexpressed in advanced Middle Eastern EOC and is strongly correlated with XIAP overexpression. Functionally, we have shown that XIAP is regulated by HGF/c-Met/AKT pathway in EOC cell lines. These studies may have important implication for treatment of EOC patient and pave the way to overcome chemotherapy resistance by targeting $\mathrm{HGF} / \mathrm{c}-$ Met signal pathway.

Our data indicate that c-Met overexpression is linked to activation of antiapoptotic markers XIAP and Bcl-XL through AKP phosphorylation in Middle Eastern EOC, inhibition of c-Met by PHA665752 causes apoptosis through activation of mitochondrial apoptotic pathway in EOC cells, and inhibition of c-Met with PHA66572 synergizes with chemotherapeutic drug, cisplatin, suggesting that c-Met/HGF pathway may be a potential target for therapeutic intervention for treatment of EOC.

Supplementary Information accompanies the paper on the Laboratory Investigation website (http://www.laboratoryinvestigation.org)

\section{ACKNOWLEDGEMENT}

We are thankful to Valorie Balde, Thara George, Hassan Al Dossarie, and Saeeda Ahmed for their technical assistance, and Zeeshan Qadri for data analysis.

\section{DISCLOSURE/CONFLICT OF INTEREST}

The authors declare no conflict of interest.

1. Philchenkov A. Caspases: potential targets for regulating cell death. J Cell Mol Med 2004;8:432-444.

2. Deveraux QL, Takahashi R, Salvesen GS, et al. X-linked IAP is a direct inhibitor of cell-death proteases. Nature 1997;388:300-304.

3. Holcik M, Gibson H, Korneluk RG. XIAP: apoptotic brake and promising therapeutic target. Apoptosis 2001;6:253-261.

4. Lacasse EC, Baird S, Korneluk RG, et al. The inhibitors of apoptosis (IAPs) and their emerging role in cancer. Oncogene 1998;17:32473259.

5. Tamm I, Kornblau SM, Segall $\mathrm{H}$, et al. Expression and prognostic significance of IAP-family genes in human cancers and myeloid leukemias. Clin Cancer Res 2000;6:1796-1803.

6. Yang L, Cao ZH, Yan H, et al. Coexistence of high levels of apoptotic signaling and inhibitor of apoptosis proteins in human tumor cells: implication for cancer specific therapy. Cancer Res 2003;63:6815-6824.

7. Mansouri A, Zhang QX, Ridgway LD, et al. Cisplatin resistance in an ovarian carcinoma is associated with a defect in programmed cell death control through XIAP regulation. Oncol Res 2003;13: 399-404.

8. Sapi $E$, Alvero $A B, C$ hen $W$, et al. Resistance of ovarian carcinoma cells to docetaxel is XIAP dependent and reversible by phenoxodiol. Oncol Res 2004;14:567-578.

9. Sasaki $H$, Sheng $Y L$, Kotsuji $F$, et al. Down-regulation of X-linked inhibitor of apoptosis protein induces apoptosis in chemoresistant human ovarian cancer cells. Cancer Res 2000;60:5659-5666.

10. La Casse EC, Cherton-Horvat GG, Hewitt KE, et al. Preclinical characterization of AEG35156/GEM 640, a second-generation antisense oligonucleotide targeting X-linked inhibitor of apoptosis. Clin Cancer Res 2006;12:5231-5241.

11. Lacasse EC, Kandimalla ER, Winocour P, et al. Application of XIAP antisense to cancer and other proliferative disorders: development of AEG35156/GEM640. Ann NY Acad Sci 2005;1058:215-234.

12. Shaw TJ, Lacasse EC, Durkin JP, et al. Downregulation of XIAP expression in ovarian cancer cells induces cell death in vitro and in vivo. Int J Cancer 2008;122:1430-1434.

13. Ma PC, Maulik G, Christensen J, et al. c-Met: structure, functions and potential for therapeutic inhibition. Cancer Metastasis Rev 2003; 22:309-325.

14. Sawada K, Radjabi AR, Shinomiya N, et al. c-Met overexpression is a prognostic factor in ovarian cancer and an effective target for inhibition of peritoneal dissemination and invasion. Cancer Res 2007;67:1670-1679.

15. Koon EC, Ma PC, Salgia R, et al. Effect of a c-Met-specific, ATPcompetitive small-molecule inhibitor SU11274 on human ovarian carcinoma cell growth, motility, and invasion. Int J Gynecol Cancer 2008;18:976-984.

16. Xiao $G H$, Jeffers $M$, Bellacosa $A$, et al. Anti-apoptotic signaling by hepatocyte growth factor/Met via the phosphatidylinositol 3-kinase/ Akt and mitogen-activated protein kinase pathways. Proc Natl Acad Sci USA 2001;98:247-252.

17. Shinomiya N, Gao CF, Xie Q, et al. RNA interference reveals that ligandindependent MET activity is required for tumor cell signaling and survival. Cancer Res 2004;64:7962-7970.

18. Uddin $\mathrm{S}$, Hussain $A R$, Al-Hussein $K A$, et al. Inhibition of phosphatidylinositol 3V-kinase/AKT signaling promotes apoptosis of primary effusion lymphoma cells. Clin Cancer Res 2005;11:3102-3108.

19. Takeuchi H, Kim J, Fujimoto A, et al. X-Linked inhibitor of apoptosis protein expression level in colorectal cancer is regulated by hepatocyte growth factor/C-met pathway via Akt signaling. Clin Cancer Res 2005;11:7621-7628.

20. Russel P. Blaustein's Pathology of the Female Genital Tract. SpringerVerlag: New York, 1995.

21. Bavi P, Abubaker J, Hussain A, et al. Reduced or absent cyclin $\mathrm{H}$ expression is an independent prognostic marker for poor outcome in diffuse large B-cell lymphoma. Hum Pathol 2008;39:885-894.

22. Uddin $S$, Bavi $P$, Hussain AR, et al. Leptin receptor expression in middle Eastern colorectal cancer and it's potential clinical implication. Carcinogenesis 2009;30:1832-1840.

23. Kang JY, Dolled-Filhart M, Ocal IT, et al. Tissue microarray analysis of hepatocyte growth factor/Met pathway components reveals a role for Met, matriptase, and hepatocyte growth factor activator inhibitor 1 in the progression of node-negative breast cancer. Cancer Res 2003;63:1101-1105.

24. Tolgay Ocal I, Dolled-Filhart M, D'Aquila TG, et al. Tissue microarraybased studies of patients with lymph node negative breast carcinoma show that met expression is associated with worse outcome but is not correlated with epidermal growth factor family receptors. Cancer 2003:97:1841-1848.

25. Lengyel E, Prechtel D, Resau JH, et al. C-Met overexpression in nodepositive breast cancer identifies patients with poor clinical outcome independent of Her2/neu. Int J Cancer 2005;113:678-682.

26. Uddin $S, B u R$, Ahmed $M$, et al. Overexpression of leptin receptor predicts an unfavorable outcome in Middle Eastern ovarian cancer. Mol Cancer 2009;8:74-85.

27. Uddin S, Ahmed M, Hussain A, et al. Cyclooxygenase-2 inhibition inhibits PI3K/AKT kinase activity in epithelial ovarian cancer. Int J Cancer 2010;126:382-394.

28. Hussain AR, Al-Rasheed M, Manogaran PS, et al. Curcumin induces apoptosis via inhibition of $\mathrm{PI} 3^{\prime}$-kinase/AKT pathway in acute $\mathrm{T}$ cell leukemias. Apoptosis 2006;11:245-254. 
29. Krishan A. Rapid flow cytofluorometric analysis of mammalian cell cycle by propidum iodide staining. J Cell Biol 1975;66:188-193.

30. Uddin S, Hussain AR, Siraj AK, et al. Role of phosphatidylinositol 3'kinase/AKT pathway in diffuse large B-cell lymphoma survival. Blood 2006;108:4178-4186.

31. Uddin S, Ah-Kang J, Ulaszek J, et al. Differentiation stage-specific activation of p38 mitogen-activated protein kinase isoforms in primary human erythroid cells. Proc Natl Acad Sci USA 2004;101:147-152.

32. Hussain AR, Al-Jomah NA, Siraj AK, et al. Sanguinarine- dependent induction of apoptosis in primary effusion lymphoma cells. Cancer Res 2007;8:3888-3897.

33. Uddin S, Hussain AR, Manogaran PS, et al. Curcumin suppresses growth and induces apoptosis in primary effusion lymphoma. Oncogene 2005;47:7022-7030.

34. Bazzaro $M$, Lee $M K$, Zoso $A$, et al. Ubiquitin-proteasome system stress sensitizes ovarian cancer to proteasome inhibitor-induced apoptosis. Cancer Res 2006;66:3754-3763

35. Sawada K, Radjabi AR, Shinomiya N, et al. c-Met overexpression is a prognostic factor in ovarian cancer and an effective target for inhibition of peritoneal dissemination and invasion. Cancer Res 2007;67:1670-1679.

36. Christensen JG, Burrows J, Salgia R. c-Met as a target for human cancer and characterization of inhibitors for therapeutic intervention. Cancer Lett 2005;1:1-26.

37. Tjin EP, Groen RW, Vogelzang I, et al. Functional analysis of HGF/MET signaling and aberrant HGF-activator expression in diffuse large B-cell lymphoma. Blood 2006;107:760-768.

38. Daugaard G. Cisplatin nephrotoxicity: experimental and clinical studies. Dan Med Bull 1990;37:1-12.

39. Verstappen $\mathrm{C}$, Heimans J, Hoekman K, et al. Neurotoxic complications of chemotherapy in patients with cancer: clinical signs and optimal management. Drugs 2003;63:1549-1563.

40. Kuhar $M$, Imran $S$, Singh N. Curcumin and quercetin combined with cisplatin to induce apoptosis in human laryngeal carcinoma Hep-2 cells through the mitochondrial pathway. J Cancer Mol 2007;3:121-128.

41. Furge KA, Zhang YW, Vande Woude GF. Met receptor tyrosine kinase: enhanced signaling through adapter proteins. Oncogene 2000; 19:5582-5589.

42. Lu CD, Altieri DC, Tanigawa N. Expression of a novel antiapoptosis gene, survivin, correlated with tumor cell apoptosis and p53 accumulation in gastric carcinomas. Cancer Res 1998;58:1808-1812.
43. Kato J, Kuwabara $Y$, Mitani $M$, et al. Expression of survivin in esophageal cancer: correlation with the prognosis and response to chemotherapy. Int J Cancer 2001;95:92-95.

44. Cao C, Mu Y, Hallahan DE, et al. XIAP and surviving as therapeutic targets for radiation sensitization in preclinical models of lung cancer. Oncogene 2004;23:7047-7052.

45. Di Renzo MF, Olivero M, Katsaros D, et al. Overexpression of the MET/ HGF receptor in ovarian cancer. Int J Cancer 1994;58:658-662.

46. Olivero M, Ruggiero T, Saviozzi S, et al. Genes regulated by hepatocyte growth factor as targets to sensitize ovarian cancer cells to cisplatin. Mol Cancer Ther 2006;5:1126-1135.

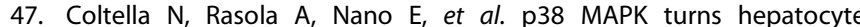
growth factor to a death signal that commits ovarian cancer cells to chemotherapy-induced apoptosis. Int J Cancer 2006;118: 2981-2990.

48. Rasola A, Anguissola S, Ferrero N, et al. Hepatocyte growth factor sensitizes human ovarian carcinoma cell lines to paclitaxel and cisplatin. Cancer Res 2004;64:1744-1750.

49. Mildner M, Eckhart L, Lengauer B, et al. Hepatocyte growth factor/ scatter factor inhibits UVB-induced apoptosis of human keratinocytes but not of keratinocyte-derived cell lines via the phosphatidylinositol 3-kinase/AKT pathway. J Biol Chem 2002;277:14146-14152.

50. Fan S, Ma YX, Wang JA, et al. The cytokine hepatocyte growth factor/ scatter factor inhibits apoptosis and enhances DNA repair by a common mechanism involving signaling through phosphatidyl inositol 3-kinase. Oncogene 2000;19:2212-2223.

51. Fan S, Wang JA, Yuan $R Q$, et al. Scatter factor protects epithelial and carcinoma cells against apoptosis induced by DNA-damaging agents. Oncogene 1998;17:131-141.

52. Okano J, Shiota G, Matsumoto K, et al. Hepatocyte growth factor exerts a proliferative effect on oval cells through the PI3K/Akt signaling pathway. Biochem Biophys Res Commun 2003;309: 298-304

53. Sonoda $Y$, Matsumoto $Y$, Funakoshi $M$, et al. Anti-apoptotic role of focal adhesion kinase (FAK). Induction of inhibitor-of apoptosis proteins and apoptosis suppression by the overexpression of FAK in a human leukemic cell line, HL-60. J Biol Chem 2000;275: 16309-16315.

54. Dan HC, Sun M, Kaneko S, et al. Akt phosphorylation and stabilization of X-linked inhibitor of apoptosis protein (XIAP). J Biol Chem 2004;279:5405-5412. 